\title{
Disparities in race/ethnicity and socioeconomic status: risk of mortality of breast cancer patients in the California Cancer Registry, 2000-2010
}

\author{
Carol A Parise* and Vincent Caggiano
}

\begin{abstract}
Background: Racial disparities in breast cancer survival have been well documented. This study examines the association of race/ethnicity and socioeconomic status (SES) on breast cancer-specific mortality in a large population of women with invasive breast cancer.

Methods: We identified 179,143 cases of stages 1-3 first primary female invasive breast cancer from the California Cancer Registry from January, 2000 through December, 2010. Cox regression, adjusted for age, year of diagnosis, grade, and ER/PR/HER2 subtype, was used to assess the association of race/ethnicity on breast cancer-specific mortality within strata of stage and SES. Hazard ratios (HR) and 95\% confidence intervals were reported.

Results: Stage 1: There was no increased risk of mortality for any race/ethnicity when compared with whites within all SES strata. Stage 2: Hispanics ( $H R=0.85 ; 0.75,0.97)$ in the lowest SES category had a reduced risk of mortality.. Blacks had the same risk of mortality as whites in the lowest SES category but an increased risk of mortality in the intermediate ( $H R=1.66 ; 1.34,2.06)$ and highest $(H R=1.41 ; 1.15,1.73)$ SES categories. Stage 3: Hispanics $(H R=0.74$; $0.64,0.85)$ and APIs $(H R=0.64 ; 0.50,0.82)$ in the lowest SES category had a reduced risk while blacks had similar mortality as whites. Blacks had an increased risk of mortality in the intermediate ( $H R=1.52 ; 1.20,1.92)$ and highest $(H R=1.53 ; 1.22,1.92)$ SES categories.

Conclusions: When analysis of breast cancer-specific mortality is adjusted for age and year of diagnosis, ER/PR/HER2 subtype, and tumor grade and cases compared within stage and SES strata, much of the black/white disparity disappears. SES plays a prominent role in breast cancer-specific mortality but it does not fully explain the racial/ethnic disparities and continued research in genetic, societal, and lifestyle factors is warranted.
\end{abstract}

Keywords: Disparities, Breast cancer-specific mortality, Race/ethnicity, Socioeconomic status

\section{Background}

Breast cancer is the most common cancer in women residing in California, regardless of age or race/ethnicity [1-3] but the burden of this cancer has an unequal racial/ethnic distribution. Racial disparities in breast cancer incidence and mortality have been well documented in the past, particularly among African American women, who have been found to have a lower incidence of breast cancer compared to white women, but a higher overall mortality $[4,5]$.

A wealth of studies have documented the many factors specifically associated with disparities of cancer care such

\footnotetext{
* Correspondence: parisec@sutterhealth.org

Sutter Institute for Medical Research, 2801 Capitol Ave Suite 400,
} Sacramento, CA 95816, USA as age, race/ethnicity, socioeconomic status (SES), access to health care, cultural, medical, and health provider issues [6-18]. Additionally, prognostic factors directly related to breast cancer including tumor size, histology, grade, nodal and receptor status, and stage at diagnosis are expressed differentially in the population by age and race/ethnicity [19-23] adding further complexity to any discussion of disparities in cancer care.

Over 40 years ago, the California Cancer Registry (CCR) noted that breast cancer patients treated at private hospitals survived their cancer better than patients treated in public hospitals [24]. Expanding on this early attempt to explain how social class or SES relates to breast cancer survival, the objective of this present investigation is to 
determine if the association of race/ethnicity on breast cancer survival persists when analyses are conducted that compare patients within the same SES category and stage at diagnosis.

\section{Methods}

Using the population-based CCR, we identified cases of American Joint Commission on Cancer (AJCC) stages 1-3 first primary female invasive breast cancer (ICDO-3 sites C50.0-C50.9) [25] diagnosed between January 1, 2000 through December 31, 2010 and reported to the CCR as of January, 2012. Cases are reported to the Cancer Surveillance Section of the California Department of Public Health from hospitals and any other facilities providing care or therapy to cancer patients residing in California [26]. Cases identified outside of California, only at autopsy, or from death certificates were excluded. Breast cancerspecific mortality was defined as a death due to breast cancer as documented by the codes ranging from C50.01 to C50.91 of the International Statistical Classification of Diseases and Related Health Problems, 10th Revision. Deaths due to causes other than cancer were censored.

\section{SES}

Quintile of SES was derived using data from the $2000 \mathrm{U}$. S. census. SES was assigned at the census block group level and based on address at time of initial diagnosis, as reported in the medical record. This area based composite SES measure was created through principal components analysis [27] and included the following census variables: proportion with a blue-collar job, proportion older than 16 years without a job, median household income, population living below 200\% Federal Poverty Level, median gross rent, median value of owner-occupied houses, and a median education index [28]. Quintiles of SES ranging from 1 (the lowest/ least affluent) to 5 (the highest/most affluent) were computed. This area based SES measure has been used in many studies utilizing cancer registry data [22,29-33]. A detailed description of this methodology is found in other publications [34].

For ease of presentation, in this study, we combined the lowest two quintiles $1+2$ (lowest/least affluent) as well as the highest two quintiles $4+5$ (highest/most affluent).The intermediate (3) remained intact.

\section{Race/ethnicity}

Race/ethnicity was classified into six distinct categories: White, African American or black, Hispanic, AsianPacific Islander (API), American Indian, and Hispanic plus other race. The race/ethnicity information contained in the medical record was obtained by patient selfidentification, assumptions based on personal appearance, or inferences based on the race/ethnicity of the parents, birthplace, surname, or maiden name. The API category was derived from combining cases identified as Pacific Islander, Southeast Asian, Indian continent, Chinese, Japanese, Filipino, and Korean.

Determination of Hispanic ethnicity was based on information from the medical record and computer-based comparisons to the 1980 U.S. census list of Hispanic surnames. Patients identified as Hispanic on the medical record as white with a Hispanic surname were classified as Hispanic. Cases identified as black or API and also identified as Hispanic were categorized as Hispanic plus other race. This classification resulted in six mutually exclusive categories: White, black, Hispanic, API, American Indian, and Hispanic plus other race.

\section{ER/PR/HER2}

The details of documentation of estrogen receptor (ER) progesterone receptor (PR), and human epidermal growth factor receptor 2 (HER2) along with age and stage at diagnosis, and tumor grade have been extensively described in our previous publications $[22,32,35,36]$. And by the CCR [26]. Age was grouped into five categories $(<35,35-69$, $70-79,80-89$, and $90+$ years). Year of diagnosis was categorized as 2000-2006 and 2007-2010. The year 2007 marks the first complete year following approval of trastuzumab for adjuvant therapy for breast cancer.

\section{Statistical analysis}

The number of cases with missing data for ER, PR, HER2, race, grade, cause of death, and survival time were computed. Contingency tables were used to assess the distribution of missing data by race, and the distribution of demographic and tumor characteristics among SES strata.

Cox proportional hazards modeling was used to determine time from breast cancer diagnosis to time of breast cancer-specific death for African Americans, Hispanics, and APIs, when compared with whites. All analyses were conducted separately for each stage because of the differences in prognosis of patients diagnosed in different stages. Separate models with and without SES were run to test whether SES confounded the association of race with mortality. The interaction between race and SES was then tested to determine if the affect of race on mortality varied among the levels of SES.

Analyses were stratified by both stage and SES so that the risk of mortality for each race could be estimated for cases within each stage/SES stratum.

All models were adjusted for age, ER/PR/HER2, grade, and year of diagnosis. Hazard ratios (HR) and 95\% Confidence Intervals (CIs) were computed for all models. The HR represents the estimated risk of mortality for two people of the same age and tumor characteristic when one person is black, Hispanic, or API, and the other person is white. 
This research study involved analysis of existing data from the California Cancer Registry without subject intervention. No identifiers were linked to subjects. Therefore, the study was approved by Sutter Health Central Institutional Review Committee under the category "exempt".

\section{Results}

\section{Missing data}

The initial data contained 181,090 cases of stages $1-3$ first primary invasive breast cancer. Cases where race was identified as American Indian $(n=275)$, Hispanic plus other race $(n=517)$, or race unknown $(n=1,155)$ were excluded, which resulted in 179,143 cases with complete data for year of diagnosis, age, race/ethnicity, stage, vital status, and SES. Tumor grade, ER/PR/HER2 status, and unknown cause of death were missing for 57,695 cases leaving 123,395 cases with complete data (Table 1).

The distribution of missing ER, PR and HER2 was similar for all race/ethnicities ranging from $8.2 \%$ to 9.8\% for ER; $10.9 \%$ to $12.6 \%$ for PR and $24.4 \%$ to $25.9 \%$ for HER2. There was little variation among the race/ ethnicities for missing grade, ranging from 5.5\% to $6.0 \%$. Cause of death was missing equally among all races $(1.2 \%$ to $1.5 \%)$.

\section{Demographics and tumor characteristics}

Table 2 shows the distribution of cases within each of the SES categories. There was no appreciable difference in the year of diagnosis among all SES categories. Of the patients within the lowest SES category, 50.2\% were white, $10.9 \%$ were black, $29.8 \%$ were Hispanic, and $9.1 \%$ were API. In contrast, within the highest SES category, the percents were $76.1 \%, 3.1 \%, 8.4 \%$, and $12.4 \%$ respectively. Over $50 \%$ of African Americans and Hispanics were in the lowest and intermediate SES categories.

Table 1 Summary of missing data for incident female stages 1-3 invasive breast cancer reported to the California Cancer Registry 2000-2010 with complete data for age, SES, year of diagnosis, survival time, and race/ethnicity $(\mathrm{N}=179,143)$

\begin{tabular}{cr}
\hline Missing & $\mathbf{n ( \% )}$ \\
\hline ER & $16,247(9.0 \%)$ \\
PR & $21,306(11.8 \%)$ \\
HER2* & $45,021(24.9 \%)$ \\
Tumor grade & $10,594(5.9 \%)$ \\
Unknown cause of death & $2,386(1.5 \%)$ \\
Total cases with one or more of the $_{\text {above variables missing }}{ }^{+}$ & $\mathbf{5 7 , 6 9 5 ( 3 1 . 9 \% )}$ \\
Total cases with complete data & \\
\hline
\end{tabular}

"HER2 data not easily retrievable in the registry until 2006

${ }^{\dagger}$ Cases may be missing data for more than one variable.
The relationship between stage and SES was informative. For patients in the lowest SES category, $43.7 \%$ were stage 1, whereas $51.7 \%$ of patients within the highest SES category had stage 1 disease. For stages 2 and 3, with each increase in an SES category a decrease in the percent of patients was noted.

A significantly higher percent of patients within the lowest SES category had the ER-/PR-HER2- and ER-/PRHER2+ subtypes when compared with the highest SES category (Table 2).

The distribution of cases by race/ethnicity is shown in Table 3. The majority of white $(58.2 \%)$ and API patients (57.9\%) were in the highest SES category. In contrast, the majority of black (51.3\%) and Hispanic patients (52.3\%) were in the lowest SES category. Of the 3,688 patients under 35 years of age, 1,600 (43.4\%) were white and 1,215 (32.9\%) were Hispanic. However, only $1.3 \%$ of white patients were less than 35 years of age, whereas $4.3 \%$ of Hispanic patients were in that age group. With each increasing age category, the percent of whites diagnosed increased progressively while the percent of all other races decreased. Over $80 \%$ of women aged 80 and older were white.

The ER+/PR+/HER2- subtype was the most common (57.2\%), but variation by race/ethnicity was noted, especially between white (60.3\%) and black patients (42.9\%). Black and Hispanic patients had the highest percent of the triple-negative subtype, $25.5 \%$ and $16.3 \%$, respectively. Whites had the lowest percent of patients among the four HER2-positive subtypes. This was especially noticeable within the ER-/PR-/HER2+ subtype, the molecularly defined HER2-overexpressing subtype, with whites having the lowest (5.5\%) and API patients the highest (9.3\%) percent.

The majority of white patients $(52.1 \%)$ presented in stage 1, compared with approximately $40 \%$ of both black and Hispanic patients presenting in this stage. A higher percent of black (15.9\%) and Hispanic (15.7\%) patients presented with stage 3 disease compared with white (9.9\%) and API (10.7\%) patients. Over 60\% of white patients presented with the ER+/PR + HER2- subtype. Among black patients, 25.5\% had ER-/PR-HER2- compared with only $11.3 \%$ of whites. African Americans, Hispanics, and API patients were diagnosed at a higher grade (Table 3 ).

\section{Cox proportional hazards}

Cox proportional hazards models adjusted for age, ER/ PR/HER2, grade, and year of diagnosis indicated that inclusion of SES was a confounder of the association of race with breast cancer-specific mortality (results not shown). SES reduced the effect of all race/ethnicities on mortality in all stages. The strength of the effect of SES was strongest for blacks in stage 1 where the HR was 
Table 2 Distribution of demographic and tumor characteristics of stages 1-3 first primary invasive breast cancer by socioeconomic status: California Cancer Registry 2000-2010*

\begin{tabular}{|c|c|c|c|c|c|}
\hline & & \multicolumn{4}{|c|}{ Socioeconomic status category } \\
\hline & & Lowest/least affluent & Intermediate & Highest/most affluent & Total \\
\hline N (\%) & & $49,868(27.8 \%)$ & $37,128(20.7 \%)$ & $92,147(51.36 \%)$ & 179,143 \\
\hline \multicolumn{6}{|l|}{ Year at diagnosis } \\
\hline \multirow{2}{*}{$2000-2006$} & $n$ & 31,380 & 23,844 & 59,359 & 114,583 \\
\hline & $\%$ within SES & $62.9 \%$ & $64.2 \%$ & $64.4 \%$ & $64.0 \%$ \\
\hline \multirow{2}{*}{$2007-2010$} & $n$ & 18,488 & 13,284 & 32,788 & 64,560 \\
\hline & $\%$ within SES & $37.1 \%$ & $35.8 \%$ & $35.6 \%$ & $36.0 \%$ \\
\hline
\end{tabular}

Race/ethnicity

$\begin{array}{ll}\text { White } & \mathrm{n} \\ & \% \text { within SES } \\ \text { Black } & \mathrm{n} \\ & \% \text { within SES } \\ \text { Hispanic } & \mathrm{n} \\ & \% \text { within SES } \\ \text { API } & \mathrm{n} \\ & \% \text { within SES }\end{array}$

$\begin{array}{ll}25,016 & 25,283 \\ 50.2 \% & 68.1 \% \\ 5,454 & 2,349 \\ 10.9 \% & 6.3 \% \\ 14,848 & 5,756 \\ 29.8 \% & 15.5 \% \\ 4,550 & 3,740 \\ 9.1 \% & 10.1 \%\end{array}$

70,136

120,435

$8.1 \%$

$76.1 \%$

$67.2 \%$

34

2,834

10,637

5,756

$3.1 \%$

$5.9 \%$

7,776

28,380

$5.5 \%$

$8.4 \%$

$15.8 \%$

$10.1 \%$

11,401

19,691

$12.4 \%$

$11.0 \%$

Age (years) at diagnosis

$$
<35
$$

35-69

70-79

80-89

$90+$

AJCC stage

Stage 1

Stage 2

Stage 3

ER/PR/HER2 subtype

$\begin{array}{ll}\text { ER+/PR+/HER2- } & \mathrm{n} \\ \text { ER+/PR+/HER2+ } & \% \text { within SES } \\ \text { ER+/PR-/HER2- } & \% \text { within SES } \\ & \% \text { within SES } \\ \text { ER+/PR-/HER2+ } & \mathrm{n} \\ & \% \text { within SES }\end{array}$

1,347

$2.7 \%$

35,557

$71.3 \%$

8,414

$16.9 \%$

4,022

$8.1 \%$

528

$1.1 \%$

21,814

$43.7 \%$

21,082

$42.3 \%$

6,972

$14.0 \%$

18,434

$52.6 \%$

3,521

$10.0 \%$

3,264

$9.3 \%$

1,180

$3.4 \%$
713

$1.9 \%$

25,924

$69.8 \%$

6,708

$18.1 \%$

3,349

$9.0 \%$

434

$1.2 \%$

18,066

$48.7 \%$

14,776

$39.8 \%$

4,286

$11.5 \%$

15,088

$56.6 \%$

2,519

$9.5 \%$

2,548

$9.6 \%$

856

$3.2 \%$

$\begin{array}{cc}1,628 & 3,688 \\ 1.8 \% & 2.1 \% \\ 66,589 & 128,070 \\ 72.3 \% & 71.5 \% \\ 15,388 & 30,510 \\ 16.7 \% & 17.0 \% \\ 7,565 & 14,936 \\ 8.2 \% & 8.3 \% \\ 977 & 1,939 \\ 1.1 \% & 1.1 \%\end{array}$

47,655

87,535

$48.9 \%$

71,408

$39.9 \%$

20,200

$11.3 \%$

$9.7 \%$

40,900

74,422

$57.2 \%$

12,244

6,204

$9.4 \%$

$9.1 \%$

12,514

6,702

9.6\%

4,118

$3.2 \%$ 
Table 2 Distribution of demographic and tumor characteristics of stages 1-3 first primary invasive breast cancer by socioeconomic status: California Cancer Registry 2000-2010* (Continued)

\begin{tabular}{|c|c|c|c|c|c|}
\hline \multirow{2}{*}{ ER-/PR+/HER2- } & $n$ & 285 & 212 & 527 & 1,024 \\
\hline & $\%$ within SES & $0.8 \%$ & $0.8 \%$ & $0.8 \%$ & $0.8 \%$ \\
\hline \multirow{2}{*}{ ER-/PR+/HER2+ } & $n$ & 167 & 120 & 226 & 513 \\
\hline & $\%$ within SES & $0.5 \%$ & $0.5 \%$ & $0.3 \%$ & $0.4 \%$ \\
\hline \multirow{2}{*}{ ER-/PR-/HER2- } & $n$ & 5,454 & 3,550 & 7,821 & 16,825 \\
\hline & $\%$ within SES & $15.6 \%$ & $13.3 \%$ & $11.4 \%$ & $100.0 \%$ \\
\hline \multirow[t]{2}{*}{ ER-/PR-/HER2+ } & $n$ & 2,744 & 1,753 & 3,941 & $12.9 \%$ \\
\hline & $\%$ within SES & $7.8 \%$ & $6.6 \%$ & $5.8 \%$ & 8,438 \\
\hline Tumor grade & $n$ & 9,276 & 7,998 & 22,058 & 39,332 \\
\hline \multirow{2}{*}{ Grade I } & $\%$ within SES & $19.9 \%$ & $22.9 \%$ & $25.3 \%$ & $23.3 \%$ \\
\hline & $n$ & 18,814 & 14,625 & 37,837 & 71,276 \\
\hline \multirow{2}{*}{ Grade II } & $\%$ within SES & $40.3 \%$ & $41.9 \%$ & $43.4 \%$ & $42.3 \%$ \\
\hline & $\mathrm{n}$ & 17,586 & 11,572 & 25,888 & 55,046 \\
\hline \multirow{2}{*}{ Grade III } & $\%$ within SES & $37.7 \%$ & $33.2 \%$ & $29.7 \%$ & $32.6 \%$ \\
\hline & $n$ & 1,001 & 698 & 1,344 & 3,043 \\
\hline Grade IV & $\%$ within SES & $2.1 \%$ & $2.0 \%$ & $1.5 \%$ & $1.8 \%$ \\
\hline
\end{tabular}

*Excludes cases classified as American Indian and Hispanic + Other race.

reduced 9.2\% from 1.32 for blacks without inclusion of SES to 1.19 when included. The models that included the interaction between SES and race/ethnicity were statistically significant for stages 2 and $3(\mathrm{p}<0.05)$ which indicated that the association of race with mortality was not the same for all levels of SES. Therefore models stratified by both stage and SES were more appropriate and these results are presented in Table 4 .

Table 4 shows that in stage 1 there was no increased risk of mortality for any race/ethnicity when compared with whites for all SES categories. In stage 2, Hispanics had a $15 \%$ reduced risk of mortality in the lowest SES category. Blacks had the same risk of mortality as whites in lowest SES category. However, in the intermediate and highest SES categories, blacks had a statistically significantly higher risk of mortality.

For stage 3, in the lowest SES category, Hispanics and APIs had a reduced risk of mortality while blacks had similar mortality as whites. In the intermediate SES category, blacks had a $52 \%$ increased risk of mortality and a 53\% increased risk in the highest SES category.

For all stages, there was no black/white disparity in the lowest SES category. However, Hispanics in the lowest SES had better survival than whites in stages 2 and 3 .

\section{Discussion}

Racial disparities in breast cancer treatment and outcomes have been previously well documented $[2,8,37,38]$. Survival differences between African American and white patients with breast cancer have often been attributed to more advanced stage at diagnosis [39], unfavorable tumor biology features such as hormone receptor-negative disease [19] or triple-negative disease [40], lower SES [5,41], and inferior use of adjuvant treatments [9,42-46].

It remains difficult to completely separate and untangle the interplay among race/ethnicity, SES, and tumor biology, and determine their respective roles in breast cancer outcomes. This dilemma is evident from the conflicting results of studies investigating racial/ethnic disparities in cancer. Some have shown comparable outcomes after adjustment for sociodemographic factors if patients have equal access to healthcare [47-52]. Others have found that low SES, not race, was associated with poorer outcomes [41,53,54].

Further, some studies have shown racial disparities even after adjusting for SES. In a meta-analysis of 20 studies representing a total of 14,013 African Americans and 76,111 white American women diagnosed with breast cancer from 1961 to 2003, Newman concluded that African American ethnicity is a significant and independent predictor of poor outcome from breast cancer, even after accounting for SES [55]. Also, a Southwest Oncology Group study concluded that, after adjustment for SES, African American patients with breast cancer had worse adjusted survival, despite enrollment on phase III clinical trials with uniform stage, treatment, and follow-up [56]. These latter studies, as well as others [57-59] suggest biologic differences in tumor behavior as the reason for racial/ethnic disparities.

Others argue against a biologic hypothesis for racial disparities. In a study of breast cancer-specific mortality rates for women in Chicago, New York City, and the 
Table 3 Distribution of demographic and tumor characteristics of stages 1-3 first primary invasive breast cancer by race/ethnicity: California Cancer Registry 2000-2010*

\begin{tabular}{|c|c|c|c|c|c|c|}
\hline & & \multicolumn{5}{|c|}{ Race/Ethnicity } \\
\hline & & White & Black & Hispanic & API & Total \\
\hline N (\%) & & $120,435(67.2 \%)$ & $10,637(5.9 \%)$ & $28,380(15.8 \%)$ & $19,691(11.1 \%)$ & 179,143 \\
\hline \multicolumn{7}{|l|}{ Year at diagnosis } \\
\hline & $n$ & 79,226 & 6,662 & 17,054 & 11,641 & 114,583 \\
\hline \multirow[t]{2}{*}{$2000-2006$} & $\%$ within race/ethnicity & $65.8 \%$ & $62.6 \%$ & $60.1 \%$ & $59.1 \%$ & $64.0 \%$ \\
\hline & $\mathrm{n}$ & 41,209 & 3,975 & 11,326 & 8,050 & 64,560 \\
\hline 2007-2010 & $\%$ within race/ethnicity & $34.2 \%$ & $37.4 \%$ & $39.9 \%$ & $40.9 \%$ & $36.0 \%$ \\
\hline \multicolumn{7}{|l|}{ Socioeconomic status } \\
\hline & $n$ & 25,016 & 5,454 & 14,848 & 4,550 & 49,868 \\
\hline \multirow[t]{2}{*}{ Lowest/Least Affluent } & $\%$ within race/ethnicity & $20.8 \%$ & $51.3 \%$ & $52.3 \%$ & $23.1 \%$ & $27.8 \%$ \\
\hline & $n$ & 25,283 & 2,349 & 5,756 & 3,740 & 37,128 \\
\hline \multirow[t]{2}{*}{ Intermediate } & $\%$ within race/ethnicity & $21.0 \%$ & $22.1 \%$ & $20.3 \%$ & $19.0 \%$ & $20.7 \%$ \\
\hline & $\mathrm{n}$ & 70,136 & 2,834 & 7,776 & 11,401 & 92,147 \\
\hline Highest/Most Affluent & $\%$ within race/ethnicity & $58.2 \%$ & $26.6 \%$ & $27.4 \%$ & $57.9 \%$ & $51.4 \%$ \\
\hline \multicolumn{7}{|l|}{ Age at diagnosis (years) } \\
\hline & $\mathrm{n}$ & 1,600 & 299 & 1,215 & 574 & 3,688 \\
\hline \multirow[t]{2}{*}{$<35$} & $\%$ within race/ethnicity & $1.3 \%$ & $2.8 \%$ & $4.3 \%$ & $2.9 \%$ & $2.1 \%$ \\
\hline & $n$ & 81,900 & 8,055 & 22,331 & 15,784 & 128,070 \\
\hline \multirow[t]{2}{*}{$35-69$} & $\%$ within race/ethnicity & $68.0 \%$ & $75.7 \%$ & $78.7 \%$ & $80.2 \%$ & $71.5 \%$ \\
\hline & $n$ & 23,132 & 1,518 & 3,466 & 2,394 & 30,510 \\
\hline \multirow[t]{2}{*}{$70-79$} & $\%$ within race/ethnicity & $19.2 \%$ & $14.3 \%$ & $12.2 \%$ & $12.2 \%$ & $17.0 \%$ \\
\hline & $n$ & 12,223 & 672 & 1,190 & 851 & 14,936 \\
\hline \multirow[t]{2}{*}{$80-89$} & $\%$ within race/ethnicity & $10.1 \%$ & $6.3 \%$ & $4.2 \%$ & $4.3 \%$ & $8.3 \%$ \\
\hline & $n$ & 1,580 & 93 & 178 & 88 & 1,939 \\
\hline $90+$ & $\%$ within race/ethnicity & $1.3 \%$ & $0.9 \%$ & $0.6 \%$ & $0.4 \%$ & $1.1 \%$ \\
\hline AJCC stage & $\mathrm{n}$ & 62,693 & 4,195 & 11,321 & 9,326 & 87,535 \\
\hline \multirow[t]{2}{*}{ Stage 1} & $\%$ within race/ethnicity & $52.1 \%$ & $39.4 \%$ & $39.9 \%$ & $47.4 \%$ & $48.9 \%$ \\
\hline & $n$ & 45,791 & 4,751 & 12,608 & 8,258 & 71,408 \\
\hline \multirow[t]{2}{*}{ Stage 2} & $\%$ within race/ethnicity & $38.0 \%$ & $44.7 \%$ & $44.4 \%$ & $41.9 \%$ & $39.9 \%$ \\
\hline & $n$ & 11,951 & 1,691 & 4,451 & 2,107 & 20,200 \\
\hline Stage 3 & $\%$ within race/ethnicity & $9.9 \%$ & $15.9 \%$ & $15.7 \%$ & $10.7 \%$ & $11.3 \%$ \\
\hline \multicolumn{7}{|l|}{ ER/PR/HER2 subtype } \\
\hline & $n$ & 52,797 & 3,240 & 10,526 & 7,859 & 74,422 \\
\hline \multirow[t]{2}{*}{$\mathrm{ER}+/ \mathrm{PR}+/ \mathrm{HER} 2-$} & $\%$ within race/ethnicity & $60.3 \%$ & $42.9 \%$ & $51.0 \%$ & $54.9 \%$ & $57.2 \%$ \\
\hline & $n$ & 7,689 & 709 & 2,181 & 1,665 & 12,244 \\
\hline \multirow[t]{2}{*}{$\mathrm{ER}+/ \mathrm{PR}+/ \mathrm{HER} 2+$} & $\%$ within race/ethnicity & $8.8 \%$ & $9.4 \%$ & $10.6 \%$ & $11.6 \%$ & $9.4 \%$ \\
\hline & $n$ & 8,791 & 735 & 1,816 & 1,172 & 12,514 \\
\hline \multirow[t]{2}{*}{$\mathrm{ER}+/ \mathrm{PR}-/ \mathrm{HER} 2-$} & $\%$ within race/ethnicity & $10.0 \%$ & $9.7 \%$ & $8.8 \%$ & $8.2 \%$ & $9.6 \%$ \\
\hline & $n$ & 2,675 & 252 & 678 & 513 & 4,118 \\
\hline \multirow[t]{2}{*}{ ER+/PR-/HER2+ } & $\%$ within race/ethnicity & $3.1 \%$ & $3.3 \%$ & $3.3 \%$ & $3.6 \%$ & $3.2 \%$ \\
\hline & $n$ & 640 & 77 & 194 & 113 & 1,024 \\
\hline \multirow[t]{2}{*}{ ER-/PR+/HER2- } & $\%$ within race/ethnicity & $0.7 \%$ & $1.0 \%$ & $0.9 \%$ & $0.8 \%$ & $0.8 \%$ \\
\hline & $n$ & 281 & 45 & 126 & 61 & 513 \\
\hline
\end{tabular}


Table 3 Distribution of demographic and tumor characteristics of stages 1-3 first primary invasive breast cancer by race/ethnicity: California Cancer Registry 2000-2010* (Continued)

\begin{tabular}{|c|c|c|c|c|c|c|}
\hline \multirow[t]{2}{*}{ ER-/PR+/HER2+ } & $\%$ within race/ethnicity & $0.3 \%$ & $0.6 \%$ & $0.6 \%$ & $0.4 \%$ & $0.4 \%$ \\
\hline & $\mathrm{n}$ & 9,924 & 1,929 & 3,371 & 1,601 & 16,825 \\
\hline \multirow[t]{2}{*}{ ER-/PR-/HER2- } & $\%$ within race/ethnicity & $11.3 \%$ & $25.5 \%$ & $16.3 \%$ & $11.2 \%$ & $12.9 \%$ \\
\hline & $n$ & 4,789 & 572 & 1,748 & 1,329 & 8,438 \\
\hline ER-/PR-/HER2+ & $\%$ within race/ethnicity & $5.5 \%$ & $7.6 \%$ & $8.5 \%$ & $9.3 \%$ & $6.5 \%$ \\
\hline Tumor grade & $\mathrm{n}$ & 29,749 & 1,516 & 4,613 & 3,454 & 39,332 \\
\hline \multirow[t]{2}{*}{ Grade I } & $\%$ within race/ethnicity & $26.2 \%$ & $15.1 \%$ & $17.3 \%$ & $18.6 \%$ & $23.3 \%$ \\
\hline & $n$ & 49,124 & 3,570 & 10,610 & 7,972 & 71,276 \\
\hline \multirow[t]{2}{*}{ Grade II } & $\%$ within race/ethnicity & $43.3 \%$ & $35.5 \%$ & $39.8 \%$ & $43.0 \%$ & $42.3 \%$ \\
\hline & $n$ & 32,747 & 4,691 & 10,823 & 6,785 & 55,046 \\
\hline \multirow[t]{2}{*}{ Grade III } & $\%$ within race/ethnicity & $28.9 \%$ & $46.7 \%$ & $40.6 \%$ & $36.6 \%$ & $32.6 \%$ \\
\hline & $n$ & 1,802 & 276 & 620 & 345 & 3,043 \\
\hline Grade IV & $\%$ within race/ethnicity & $1.6 \%$ & $2.7 \%$ & $2.3 \%$ & $1.9 \%$ & $1.8 \%$ \\
\hline
\end{tabular}

*Excludes cases classified as American Indian and Hispanic + Other race.

United States from 1980-2005, race-specific rate ratios were used to measure the disparity in breast cancerspecific mortality. In all three locations the black and white rates were similar in the 1980s and remained that way until the 1990s, when the white rates started to decline while the black rates remained constant, just as the benefits from early detection by mammography and from treatment were noticeable [60-62]. These findings seem to argue against differential tumor biology.

The goal of our present study was to assess racial/ethnic disparities within three levels of SES and within the same stage of disease so that variability among treatment and access to care would be minimized. We also adjusted for ER/PR/HER2 because of the known propensity of African American and Hispanic women to have hormone receptor-negative and, in particular, triple-negative phenotype $[16,19,22,40]$.

The present investigation has shown that for women with stage 1 breast cancer, there is no disparity among any race/ethnicity regardless of the SES category. In addition, there is no black/white disparity within the lowest SES category regardless of stage of disease, but a disparity is apparent in the higher SES categories. African Americans in the intermediate and highest SES categories with stages 2 and 3 breast cancer have increased risk of mortality when compared with whites. Interestingly, low SES Hispanic patients with stages 2 and 3 disease have a lower risk of mortality when compared to low SES white patients, similar to what has been described in the "Hispanic Paradox" [63].

As is often the case, a correlational study raises more questions than answers. On the one hand, a differential tumor or host biology does not seem to be plausible because there were no differences in risk of mortality among any race/ethnicity in stage 1 and there was no black/ white disparity for women in the lowest SES category regardless of stage. On the other hand, for higher stages of disease, black patients in the same, higher SES category had an increased risk of mortality as compared to white patients while Hispanics in the lowest SES category at higher stages had decreased risk of mortality as did APIs in Stage 3.

The findings of this study raise the question of whether tumor or host factors play a role in advanced stages of disease. Do black, white, Hispanic, and API patients respond differentially to treatments? Data regarding racial/ethnic differences in the pharmcogenomics of chemotherapy and endocrine response and toxicities are limited [64-66]. Alternatively, are more aggressive treatments offered or available to patients of all race/ethnicities even when there is presumed equal access to care? Is there an element of racial/ethnic discrimination in receipt of more aggressive cancer treatments $[62,67,68]$ ?

The results of this population-based registry study cannot definitively answer these perplexing questions, but at least in stage 1 disease, a differential tumor biology appears unlikely. It also appears that SES plays a prominent role in cancer outcomes although genetic, environmental, societal, lifestyle, and health provider factors may also contribute to racial disparities, and they should not be overlooked [69].

The limitations of population-based cancer registry investigations including exclusion of subjects without ER, PR, and HER2 are well known [22,32,45,70-72]. Accurate and precise treatment information was not available from the registry. Although it has been suggested that suboptimal use of adjuvant treatments may explain differences in outcomes, $[9,42-46]$ others have reported little or 
Table 4 Hazard ratios and $95 \%$ confidence intervals derived from Cox regression for race/ethnicity after adjustment for age, year of diagnosis, grade, and ER/PR/HER2 subtype*

\begin{tabular}{l} 
Stage 1 \\
SES \\
\hline Lowest/least affluent $(n=14,011)$ \\
White \\
Black \\
Hispanic \\
API \\
Intermediate $(n=11,839)$ \\
White \\
Black \\
Hispanic \\
API \\
Highest/most affluent $(n=32,945)$ \\
White \\
Black \\
Hispanic \\
API
\end{tabular}

Stage 2

SES

Lowest/least affluent $(14,063)$

White
Black
Hispanic
API

Intermediate $(10,141)$

White

Black

Hispanic

API

Highest/most affluent $(25,323)$

White

Black

Hispanic

API

Stage 3

SES

Lowest/least affluent $(4,805)$

White
Black
Hispanic
API

Intermediate $(3,087)$

White
HR (95\% Cl)

\subsection{0}

$1.19(0.85,1.65)$

$0.96(0.74,1.13)$

$0.69(0.43,1.11)$

1.00

$0.88(0.51,1.54)$

$0.93(0.64,1.36)$

$0.92(0.59,1.43)$

1.00

$1.47(0.96,2.27)$

$1.05(0.76,1.44)$

$0.84(0.63,1.13)$

$1.14(0.97,1.38)$

$0.85(0.75,0.97)$

$0.85(0.69,1.04)$

1.00

$1.66(1.34,2.06)$

$1.11(0.92,1.32)$

$0.80(0.62,1.03)$

1.00

$1.41(1.15,1.73)$

$1.12(0.95,1.31)$

$0.92(0.79,1.07)$

1.00

$1.05(0.88,1.25)$

$0.74(0.64,0.85)$

$0.64(0.50,0.83)$

1.00
Table 4 Hazard ratios and $95 \%$ confidence intervals derived from Cox regression for race/ethnicity after adjustment for age, year of diagnosis, grade, and ER/PR/HER2 subtype* (Continued)

\begin{tabular}{lc}
\hline Black & $1.52(1.20,1.92)$ \\
Hispanic & $1.12(0.91,1.37)$ \\
API & $0.92(0.69,1.23)$ \\
Highest/most affluent (6,532) & 1.00 \\
White & $1.53(1.22,1.92)$ \\
Black & $0.97(0.79,1.17)$ \\
Hispanic & $0.92(0.76,1.11)$ \\
API & \\
*Confidence intervals that include 1.00 indicate that the risk of mortality for a \\
race/ethnicity was not statistically significantly better or worse than for whites \\
within a stage/SES stratum.
\end{tabular}

no differences between black and white patients with regard to chemotherapy administration [73-75]. Differences in adjuvant treatment between black and white women may explain the disparities we noted in stages 2 and 3 $[76,77]$. However, since the disparities occurred only in the two highest SES categories, we can speculate that patients of all race/ethnicities should have had equal access to adjuvant treatment.

We recognize that determination of race/ethnicity can be problematic and arbitrary. Hispanic ethnicity may include women from Mexico, Central and South America, Spain, as well as Puerto Rico and Cuba. The category API may include women from Asia, the Indian Continent, and the Pacific Islands. We also recognize that our measure of SES was at the neighborhood level rather than at the individual level. The CCR does not obtain the information necessary to determine individual SES but others have commented on the usefulness of composite SES measures [78,79] In addition, this measure of SES has been used in many studies that utilize cancer registry data [22,29-33].

Lastly, other than age, we have no information about reproductive history and lifestyle risk factors such as nulliparity, multiparity, breast feeding, diet, body fat distribution, use of alcohol, oral contraceptives, or hormone replacement treatments that may determine the type of breast cancer and ultimately impact survival, [80-88].

Despite these shortcomings, our study is unique because of the large number of cases reported to the statewide cancer registry from an ethnically diverse population. Unlike other studies that employed different methodologies of SES [55] or had extensive missing SES information $[56,89,90]$, we used a validated measure of SES for all 179,143 patients and most importantly, we stratified by both stage and SES to minimize the potential that our results would be due to differences either in severity of disease or access to care. 


\section{Conclusions}

Our research has shown that when breast cancerspecific mortality is analyzed either by race/ethnicity or by SES, significant differences exist among the races with respect to age at presentation, stage at diagnosis, ER/PR/HER2 subtype, and tumor grade. However, when adjusting analyses for these variables and comparing cases within stage and SES strata, much of the black/ white disparity disappears.

SES plays a prominent role in breast cancer-specific mortality but it does not fully explain the racial/ethnic disparities and continued research in genetic, societal, and lifestyle factors is warranted.

\section{Competing interests}

The authors declare that they have no competing interests.

\section{Authors' contributions}

Both authors have contributed equally to the conception and preparation of this manuscript. Both authors read and approved the final manuscript.

\section{Acknowledgements}

This study was funded by a grant from the Sutter Institute for Medical Research.

The collection of cancer incidence data used in this study was supported by the California Department of Public Health as part of the statewide cancer reporting program mandated by California Health and Safety Code Section 103885; the National Cancer Institute's Surveillance, Epidemiology and End Results Program under contract N01-PC-35136 awarded to the Northern California Cancer Center, contract N01-PC-35139 awarded to the University of Southern California, and contract N01-PC-54404 awarded to the Public Health Institute; and the Centers for Disease Control and Prevention's National Program of Cancer Registries, under agreement 1U58DP00807-01 awarded to the Public Health Institute. The ideas and opinions expressed herein are those of the authors and endorsement by the State of California Department of Public Health the National Cancer Institute, and the Centers for Disease Control and Prevention or their Contractors and Subcontractors is not intended nor should be inferred.

We would like to thank Theresa Johnson and Sharon Babcock of the Sutter Resource Library for their invaluable assistance.

Received: 12 March 2013 Accepted: 26 September 2013

Published: 2 October 2013

\section{References}

1. American Cancer Society: California Department of Public Health, California Cancer Registry. California Cancer Facts and Figures 2012. Oakland, CA American Cancer Society, California Division; 2011.

2. Campleman S, Curtis R: Demographic aspects of breast cancer incidence and mortality in California, 1988-1999. In Breast Cancer in California, 2003. Volume July. Edited by Morris C, Kwong SL. Sacramento, CA: California Department of Health Services, Cancer Surveillance Section; 2004.

3. Hofer BM, Kwong SL, Allen M, Bates JH, McCusker ME, Snipes KP: Cancer in California, 2008, Special Highlight on Cancer by Race and Ethnicity. Sacramento, CA: California Department of Public Health Cancer Surveillance Section; 2008.

4. Ries L, Eisner M, Kosary M: SEER Cancer Statistics Review, 1975-2000. Bethesda, MD: National Cancer Institute; 2003.

5. Eley JW, Hill HA, Chen WW, Austin DF, Wesley MN, Muss HB, Greenberg RS, Coates RJ, Correa P, Redmond CK, et al: Racial differences in survival from breast cancer. Results of the National Cancer Institute Black/White Cancer Survival Study. Jama 1994, 272(12):947-954.

6. Swanson GM, Lin CS: Survival patterns among younger women with breast cancer: the effects of age, race, stage, and treatment. J Natl Cancer Inst Monogr 1994, 16:69-77.

7. Joslyn SA, West MM: Racial differences in breast carcinoma survival. Cancer 2000, 88(1):114-123.
8. Shavers $\mathrm{VL}$, Brown ML: Racial and ethnic disparities in the receipt of cancer treatment. J Natl Cancer Inst 2002, 94(5):334-357.

9. Shavers VL, Harlan LC, Stevens JL: Racial/ethnic variation in clinical presentation, treatment, and survival among breast cancer patients under age 35. Cancer 2003, 97(1):134-147.

10. Smedley R, Stith A, Nelson: Unequal treatment: Confronting racial and ethnic disparities in healthcare. Washington DC: National Academies Press; 2003

11. Chlebowski RT, Chen Z, Anderson GL, Rohan T, Aragaki A, Lane D, Dolan NC, Paskett ED, McTiernan A, Hubbell FA, et al: Ethnicity and breast cancer: factors influencing differences in incidence and outcome. J Nat/ Cancer Inst 2005, 97(6):439-448.

12. Hershman D, McBride R, Jacobson JS, Lamerato L, Roberts K, Grann VR, Neugut Al: Racial disparities in treatment and survival among women with early-stage breast cancer. J Clin Oncol 2005, 23(27):6639-6646.

13. Bigby J, Holmes MD: Disparities across the breast cancer continuum Cancer Causes Control 2005, 16(1):35-44

14. Barr DA: Health Disparities in the United States: Social Class, Race, Ethnicity and Health. Baltimore: The Johns Hopkins Press; 2008

15. Deshpande AD, Jeffe DB, Gnerlich J, lqbal AZ, Thummalakunta A, Margenthaler JA: Racial disparities in breast cancer survival: an analysis by age and stage. J Surg Res 2009, 153(1):105-113.

16. Menashe I, Anderson WF, Jatoi I, Rosenberg PS: Underlying causes of the black-white racial disparity in breast cancer mortality: a populationbased analysis. J Natl Cancer Inst 2009, 101(14):993-1000.

17. Ademuyiwa FO, Edge SB, Erwin DO, Orom H, Ambrosone CB, Underwood W 3rd: Breast cancer racial disparities: unanswered questions. Cancer Res 2011, 71(3):640-644.

18. Raghavan D: Slow progress in cancer care disparities: HIPAA, PPACA, and CHEWBACCA... but were still not there! Oncologist 2011, 16(7):917-919.

19. Gapstur SM, Dupuis J, Gann P, Collila S, Winchester DP: Hormone receptor status of breast tumors in black, Hispanic, and non-Hispanic white women. An analysis of 13,239 cases. Cancer 1996, 77(8):1465-1471.

20. Joslyn SA: Hormone receptors in breast cancer: racial differences in distribution and survival. Breast Cancer Res Treat 2002, 73(1):45-59.

21. Ademuyiwa FO, Olopade Ol: Racial differences in genetic factors associated with breast cancer. Cancer Metastasis Rev 2003, 22(1):47-53.

22. Bauer KR, Brown M, Cress RD, Parise CA, Caggiano V: Descriptive analysis of estrogen receptor (ER)-negative, progesterone receptor (PR)-negative, and HER2-negative invasive breast cancer, the so-called triple-negative phenotype: a population-based study from the California cancer Registry. Cancer 2007, 109(9):1721-1728.

23. Parise CA, Bauer KR, Caggiano V: Variation in breast cancer subtypes with age and race/ethnicity. Crit Rev Oncol Hematol 2010, 76(1):44-52.

24. Linden $\mathrm{G}$ : The influence of social class in the survival of cancer patients. Am J Public Health Nations Health 1969, 59(2):267-274.

25. Fritz AG: International classification of diseases for oncology : ICD-O. 3rd edition. Geneva: World Health Organization, Geneva; 2000:239. vi.

26. Cancer reporting in California: Abstracting and coding procedures for hospitals. California cancer reporting system standards, Volume I. Sacramento, CA: California Department of Public, Cancer Surveillance and Research Branch; 2008.

27. Yost K, Perkins C, Cohen R, Morris C, Wright W: Socioeconomic status and breast cancer incidence in California for different race/ethnic groups. Cancer Causes Control 2001, 12(8):703-711.

28. Liu L, Deapen D, Bernstein L: Socioeconomic status and cancers of the female breast and reproductive organs: a comparison across racial/ ethnic populations in Los Angeles County, California (United States). Cancer Causes Control 1998, 9(4):369-380.

29. Clarke CA, Glaser SL, Keegan TH, Stroup A: Neighborhood socioeconomic status and Hodgkin's lymphoma incidence in California. Cancer Epidemiol Biomarkers Prev 2005, 14(6):1441-1447.

30. Parikh-Patel A, Bates $\mathrm{JH}$, Campleman S: Colorectal cancer stage at diagnosis by socioeconomic and urban/rural status in California, 1988-2000. Cancer 2006, 107(5 Suppl):1189-1195.

31. Zell JA, Rhee JM, Ziogas A, Lipkin SM, Anton-Culver H: Race, socioeconomic status, treatment, and survival time among pancreatic cancer cases in California. Cancer Epidemiol Biomarkers Prev 2007, 16(3):546-552.

32. Brown M, Tsodikov A, Bauer KR, Parise CA, Caggiano V: The role of human epidermal growth factor receptor 2 in the survival of women with estrogen and progesterone receptor-negative, invasive breast cancer: The California Cancer Registry, 1999-2004. Cancer 2008, 112(4):737-747. 
33. Ou SH, Zell JA, Ziogas A, Anton-Culver H: Low socioeconomic status is a poor prognostic factor for survival in stage I nonsmall cell lung cancer and is independent of surgical treatment, race, and marital status. Cancer 2008, 112(9):2011-2020.

34. Yin D, Morris C, Allen M, Cress R, Bates J, Liu L: Does socioeconomic disparity in cancer incidence vary across racial/ethnic groups? Cancer Causes Control 2010, 21(10):1721-1730.

35. Parise CA, Bauer KR, Brown MM, Caggiano V: Breast cancer subtypes as defined by the estrogen receptor (ER), progesterone receptor (PR), and the human epidermal growth factor receptor 2 (HER2) among women with invasive breast cancer in California, 1999-2004. Breast J 2009, 15(6):593-602

36. Bauer K, Parise C, Caggiano V: Use of ER/PR/HER2 subtypes in conjunction with the 2007 St Gallen Consensus Statement for early breast cancer. BMC Cancer 2010, 10:228

37. Demicheli R, Retsky MW, Hrushesky WJ, Baum M, Gukas ID, Jatoi I: Racial disparities in breast cancer outcome: insights into host-tumor interactions. Cancer 2007, 110(9):1880-1888

38. Gross CP, Smith BD, Wolf E, Andersen M: Racial disparities in cancer therapy: did the gap narrow between 1992 and 2002? Cancer 2008, 112(4):900-908.

39. Bach PB, Guadagnoli E, Schrag D, Schussler N, Warren JL: Patient demographic and socioeconomic characteristics in the SEER-Medicare database applications and limitations. Med Care 2002, 40(8 Suppl):IV-19-IV-25.

40. Amirikia KC, Mills P, Bush J, Newman LA: Higher population-based incidence rates of triple-negative breast cancer among young AfricanAmerican women: Implications for breast cancer screening recommendations. Cancer 2011, 117(12):2747-2753.

41. Bradley CJ, Given CW, Roberts C: Race, socioeconomic status, and breast cancer treatment and survival. J Natl Cancer Inst 2002, 94(7):490-496.

42. Dragun AE, Huang B, Tucker TC, Spanos WJ: Disparities in the application of adjuvant radiotherapy after breast-conserving surgery for early stage breast cancer: impact on overall survival. Cancer 2011, 117(12):2590-2598.

43. Bickell NA, Wang JJ, Oluwole S, Schrag D, Godfrey H, Hiotis K, Mendez J, Guth AA: Missed opportunities: racial disparities in adjuvant breast cancer treatment. J Clin Oncol 2006, 24(9):1357-1362.

44. Lund MJ, Brawley OP, Ward KC, Young JL, Gabram SS, Eley JW: Parity and disparity in first course treatment of invasive breast cancer. Breast Cancer Res Treat 2008, 109(3):545-557.

45. Li Cl, Daling JR, Malone KE: Incidence of invasive breast cancer by hormone receptor status from 1992 to 1998. J Clin Oncol 2003, 21(1):28-34.

46. van Ravesteyn NT, Schechter CB, Near AM, Heijnsdijk EA, Stoto MA, Draisma G, de Koning HJ, Mandelblatt JS: Race-specific impact of natural history, mammography screening, and adjuvant treatment on breast cancer mortality rates in the United States. Cancer Epidemiol Biomarkers Prev 2011, 20(1):112-122.

47. Roach M 3rd, Cirrincione C, Budman D, Hayes D, Berry D, Younger J, Hart R, Henderson IC: Race and survival from breast cancer: based on Cancer and Leukemia Group B trial 8541. Cancer J Sci Am 1997, 3(2):107-112.

48. Curtis E, Quale C, Haggstrom D, Smith-Bindman R: Racial and ethnic differences in breast cancer survival: how much is explained by screening, tumor severity, biology, treatment, comorbidities, and demographics? Cancer 2008, 112(1):171-180.

49. Du XL, Fang S, Meyer TE: Impact of treatment and socioeconomic status on racial disparities in survival among older women with breast cancer. Am J Clin Oncol 2008, 31(2):125-132.

50. Chu QD, Smith MH, Williams M, Panu L, Johnson LW, Shi R, Li BD, Glass J: Race/Ethnicity has no effect on outcome for breast cancer patients treated at an academic center with a public hospital. Cancer Epidemiol Biomarkers Prev 2009, 18(8):2157-2161

51. Vona-Davis L, Rose DP: The influence of socioeconomic disparities on breast cancer tumor biology and prognosis: a review. J Womens Health (Larchmt) 2009, 18(6):883-893.

52. Komenaka IK, Martinez ME, Pennington RE Jr, Hsu CH, Clare SE, Thompson PA, Murphy C, Zork NM, Goulet RJ Jr: Race and ethnicity and breast cancer outcomes in an underinsured population. J Natl Cancer Inst 2010, 102(15):1178-1187.

53. Byers TE, Wolf HJ, Bauer KR, Bolick-Aldrich S, Chen WW, Finch JL, Fulton JP, Schymura MJ, Shen T, Van Heest S, et al: The impact of socioeconomic status on survival after cancer in the United States: findings from the
National Program of Cancer Registries Patterns of Care Study. Cancer 2008, 113(3):582-591.

54. Sprague BL, Trentham-Dietz A, Gangnon RE, Ramchandani R, Hampton JM, Robert SA, Remington PL, Newcomb PA: Socioeconomic status and survival after an invasive breast cancer diagnosis. Cancer 2011, 117(7):1542-1551.

55. Newman LA, Griffith KA, Jatoi I, Simon MS, Crowe JP, Colditz GA: Metaanalysis of survival in African American and white American patients with breast cancer: ethnicity compared with socioeconomic status. J Clin Oncol 2006, 24(9):1342-1349.

56. Albain KS, Unger JM, Crowley JJ, Coltman CA Jr, Hershman DL: Racial disparities in cancer survival among randomized clinical trials patients of the Southwest Oncology Group. J Natl Cancer Inst 2009, 101(14):984-992.

57. Huo D, Ikpatt F, Khramtsov A, Dangou JM, Nanda R, Dignam J, Zhang B, Grushko T, Zhang C, Oluwasola O, et al: Population differences in breast cancer: survey in indigenous African women reveals over-representation of triple-negative breast cancer. J Clin Oncol 2009, 27(27):4515-4521.

58. Stark A, Kleer CG, Martin I, Awuah B, Nsiah-Asare A, Takyi V, Braman M, Quayson SE, Zarbo R, Wicha M, et al: African ancestry and higher prevalence of triple-negative breast cancer: findings from an international study. Cancer 2010, 116(21):4926-4932.

59. Henderson BE, Lee $N H$, Seewaldt $V$, Shen $H$ : The influence of race and ethnicity on the biology of cancer. Nat Rev Cancer 2012, 12(9):648-653.

60. Jones BA, Patterson EA, Calvocoressi L: Mammography screening in African American women: evaluating the research. Cancer 2003, 97(1 Suppl):258-272.

61. Berry DA, Cronin KA, Plevritis SK, Fryback DG, Clarke L, Zelen M, Mandelblatt JS, Yakovlev AY, Habbema JD, Feuer EJ: Effect of screening and adjuvant therapy on mortality from breast cancer. N Engl J Med 2005, 353(17):1784-1792.

62. Whitman S, Ansell D, Orsi J, Francois T: The racial disparity in breast cancer mortality. J Community Health 2011, 36(4):588-596.

63. Turra CM, Goldman N: Socioeconomic differences in mortality among U.S adults: insights into the Hispanic paradox. J Gerontol B Psychol Sci Soc Sci 2007, 62(3):S184-S192.

64. Patel TA, Colon-Otero G, Bueno Hume C, Copland JA 3rd, Perez EA: Breast cancer in Latinas: gene expression, differential response to treatments, and differential toxicities in Latinas compared with other population groups. Oncologist 2010, 15(5):466-475.

65. O'Donnell PH, Dolan ME: Cancer pharmacoethnicity: ethnic differences in susceptibility to the effects of chemotherapy. Clin Cancer Res 2009, 15(15):4806-4814.

66. Reding KW, Chen C, Lowe K, Doody DR, Carlson CS, Chen CT, Houck J, Weiss LK, Marchbanks PA, Bernstein L, et al: Estrogen-related genes and their contribution to racial differences in breast cancer risk. Cancer Causes Control 2012, 23(5):671-681.

67. Brawley OW: Is race really a negative prognostic factor for cancer? J Nat Cancer Inst 2009, 101(14):970-971.

68. Shavers VL, Fagan P, Jones D, Klein WM, Boyington J, Moten C, Rorie E: The state of research on racial/ethnic discrimination in the receipt of health care. Am J Public Health 2012, 102(5):953-966.

69. Wallace TA, Martin DN, Ambs S: Interactions among genes, tumor biology and the environment in cancer health disparities: examining the evidence on a national and global scale. Carcinogenesis 2011, 32(8):1107-1121.

70. Bauer KR, Brown M, Creech C, Schlag NC, Caggiano V: Data quality assessment of HER2 in the Sacramento Region of the California Cancer Registry. J Reg Manage 2007, 34(1):4-7.

71. Dunnwald LK, Rossing MA, Li Cl: Hormone receptor status, tumor characteristics, and prognosis: a prospective cohort of breast cancer patients. Breast Cancer Res 2007, 9(1):R6.

72. Grann VR, Troxel AB, Zojwalla NJ, Jacobson JS, Hershman D, Neugut Al: Hormone receptor status and survival in a population-based cohort of patients with breast carcinoma. Cancer 2005, 103(11):2241-2251.

73. Muss HB, Hunter CP, Wesley M, Correa P, Chen WW, Greenberg RS, Eley JW Austin DF, Kurman R, Edwards BK: Treatment plans for black and white women with stage II node-positive breast cancer. The National Cancer Institute Black/White Cancer Survival Study experience. Cancer 1992, 70(10):2460-2467.

74. Harlan LC, Abrams J, Warren JL, Clegg L, Stevens J, Ballard-Barbash R: Adjuvant therapy for breast cancer: practice patterns of community physicians. J Clin Oncol 2002, 20(7):1809-1817. 
75. Griggs Jj: Role of nonclinical factors in the receipt of high-quality systemic adjuvant breast cancer treatment. J Clin Oncol 2012, 30(2):121-124.

76. Rizzo M, Lund MJ, Mosunjac M, Bumpers H, Holmes L, O'Regan R, Brawley OW, Gabram S: Characteristics and treatment modalities for African American women diagnosed with stage III breast cancer. Cancer 2009, 115(13):3009-3015.

77. Sail K, Franzini L, Lairson D, Du X: Differences in treatment and survival among African-American and Caucasian women with early stage operable breast cancer. Ethn Health 2012, 17(3):309-323.

78. Krieger N: Overcoming the absence of socioeconomic data in medical records: validation and application of a census-based methodology. Am J Public Health 1992, 82(5):703-710.

79. Shavers VL: Measurement of socioeconomic status in health disparities research. J Natl Med Assoc 2007, 99(9):1013-1023.

80. Bernstein $L$, Teal CR, Joslyn S, Wilson J: Ethnicity-related variation in breast cancer risk factors. Cancer 2003, 97(1 Suppl):222-229.

81. Colditz GA, Rosner BA, Chen WY, Holmes MD, Hankinson SE: Risk factors for breast cancer according to estrogen and progesterone receptor status. J Natl Cancer Inst 2004, 96(3):218-228.

82. Ursin G, Bernstein L, Lord SJ, Karim R, Deapen D, Press MF, Daling JR, Norman SA, Liff JM, Marchbanks PA, et al: Reproductive factors and subtypes of breast cancer defined by hormone receptor and histology. Br J Cancer 2005, 93(3):364-371.

83. Ma H, Bernstein L, Pike MC, Ursin G: Reproductive factors and breast cancer risk according to joint estrogen and progesterone receptor status: a meta-analysis of epidemiological studies. Breast Cancer Res 2006, 8(4):R43.

84. Gerend MA, Pai M: Social determinants of Black-White disparities in breast cancer mortality: a review. Cancer Epidemiol Biomarkers Prev 2008, 17(11):2913-2923.

85. Shinde SS, Forman MR, Kuerer HM, Yan K, Peintinger F, Hunt KK, Hortobagyi GN, Pusztai L, Symmans WF: Higher parity and shorter breastfeeding duration: association with triple-negative phenotype of breast cancer. Cancer 2010, 116(21):4933-4943.

86. Harris HR, Willett WC, Terry KL, Michels KB: Body fat distribution and risk of premenopausal breast cancer in the Nurses' Health Study II. J Natl Cancer Inst 2011, 103(3):273-278

87. Phipps Al, Chlebowski RT, Prentice R, McTiernan A, Wactawski-Wende J, Kuller LH, Adams-Campbell LL, Lane D, Stefanick ML, Vitolins M, et al: Reproductive history and oral contraceptive use in relation to risk of triple-negative breast cancer. J Natl Cancer Inst 2011, 103(6):470-477.

88. Bernstein L, Lacey JV Jr: Receptors, associations, and risk factor differences by breast cancer subtypes: positive or negative? J Natl Cancer Inst 2011, 103(6):451-453.

89. Montoya MJ, Kent EE: Re: Racial disparities in cancer survival among randomized clinical trials of the Southwest Oncology Group. J Natl Cancer Inst 2010, 102(4):277-278.

90. Trivers KF, Messer LC, Kaufman JS: Re: Racial disparities in cancer survival among randomized clinical trials of the Southwest Oncology Group. J Natl Cancer Inst 2010, 102(4):278-279.

\section{Submit your next manuscript to BioMed Central and take full advantage of:}

- Convenient online submission

- Thorough peer review

- No space constraints or color figure charges

- Immediate publication on acceptance

- Inclusion in PubMed, CAS, Scopus and Google Scholar

- Research which is freely available for redistribution

Submit your manuscript at www.biomedcentral.com/submit 